Article

\title{
Public Discourse on Human Trafficking in International Issue Arenas
}

\author{
Niina Meriläinen * and Marita Vos \\ Department of Communication, University of Jyvaskyla, P.O. Box 35 (OPK), Jyvaskyla FI-40014, \\ Finland; E-Mail: marita.vos@jyu.fi
}

* Author to whom correspondence should be addressed; E-Mail: niina.j.merilainen@jyu.fi; Tel.: +358-50-3319-441.

Academic Editor: Valerie Zawilski

Received: 19 June 2014 / Accepted: 4 January 2015 / Published: 12 January 2015

\begin{abstract}
The purpose of this study is to better understand how the complex problem of human trafficking is addressed in international debates. How the discussion about human trafficking develops and how it is debated ultimately influences how the decision-making process unfolds. In order to understand the formation of public policy and laws, therefore, it is important to study the debate that occurs prior to decision making. This analysis focuses on the narratives used by major, well-established human rights and political actors that argue for necessary actions to be undertaken—such as the formation of new policies and laws in the European Union-as an attempt to protect citizens of the EU and other regions in the world from becoming victims of trafficking networks. Our research examines how the topic of human trafficking is framed and how this framework is intertwined in the debate with other social problems. We focus on how human trafficking is discussed by two well-established human rights Non-Governmental Organizations (NGOs), Amnesty International (Amnesty) and Human Rights Watch (HRW), in addition to the European Parliament (EP). The research questions for this study include: (1) In what context is human trafficking discussed by the three actors? (2) How do these actors frame the definition of human trafficking in their presentations? To answer these questions, we have conducted a systematic content analysis of documents that include official statements and research reports of the NGOs, as well as resolutions and recommendations of the EP. Altogether, 240 documents were analyzed in detail. These findings indicate that the two human rights organizations, Amnesty and Human Rights Watch, along with the European Parliament, all address human trafficking as an important social problem, albeit to varying degrees. Each
\end{abstract}


actor has a different method of correlating human trafficking with many other social problems, thereby emphasizing different causes and effects. In our analysis, we examine the concept of framing and, in particular, responsibility framing in order to understand the causal relationships between actors and events. The findings of this study suggest that the formation of various social policies and laws in the international political forum are deeply affected by the dynamic interrelatedness between the political issues, actors, and form and content of the debates about human trafficking that precede the formation or revision of a policy and law.

Keywords: human trafficking; human rights; communication; issue arenas

\section{Introduction}

Human trafficking is a challenging social problem to overcome. The causes and effects are interwoven, and there are no easy solutions that are readily available. Pettigrew [1] (p. 233) states that in order to find a solution, the "demands have to be communicated". This also underlines the importance of communication for human rights organizations, as debates precede decision making and policy formation. Thus, a discussion about the problems and solutions that surround this controversial issue is a precondition for the decision-making process, which includes the formation of laws and policies that address this human rights issue. This observation has special relevance for this study, as the purpose of this research is to better understand how human trafficking is addressed in the public discourse.

In particular, the focus of this study is on well-established human rights and political actors, and how they frame the issue and possibly intertwine it with other issues. By analyzing social narratives that are based on documents by the different actors, we have determined how each social and political debate is structured and how each actor has framed the issue. Subsequently, this analysis demonstrates how these arguments are amalgamated into the presentations of the actors, and we can then see if there are any differences in the way that the problems are addressed by the actors. By revealing different views, interests, and power plays that may either hinder or facilitate developing a consensus to find a solution for this complex problem, we can then examine how the negotiation of meaning takes place. Moreover, a better understanding of the context wherein human trafficking is discussed and how the issue is framed can offer us insight into what are seen by the actors as causal reasons behind human trafficking, thereby helping us find ways to resolve this difficult problem in the later stage of policy and law formulation.

The paper is structured as follows. First, we will share our insights on how human rights issues are discussed in the public arena. We will introduce the issue of human trafficking by briefly looking at how it has been addressed in the literature. Second, the research methodology that we have used to analyze the 240 documented presentations by three international actors on human rights issues will be described. Third, we will present our results and discuss relevant theories that explain our findings. 


\section{Human Rights Issues}

Human rights are political. How we define what human rights are is a common topic of discussion by individual people, non-governmental organizations (NGOs), and traditional political actors such as parliaments. NGOs and parliaments are both political actors. Although treaties and policies are made by a few established political actors, many people and organizations are actually involved in shaping the political decision-making process. Various groups and organizations, which are members of civil society, as well as private actors involved in agenda setting [2], contribute to this process. NGOs have been involved in developing international laws and formulating and implementing public norms. They therefore act in a similar manner to political parties [3]. Joachim [4] (p. 268) in turn argues that "NGOs engage in strategic framing processes to set the agenda in three stages: the definition of problems, the development of solutions or policies, and politicization.” NGOs have become key political powers that set the agenda, frame, and promote various power strategies [5]. Murdie [6] found that human rights NGOs do have a political impact on the policy-making process and this can then have a moderate impact on human rights performance.

Dahre [7] argues that human rights are political instruments and the discourse about human rights is about influence, force, and political power. This discourse is political by nature, thus calling for both social and political solutions. Human rights do not appear and disappear by themselves. As Ibhawoh [8] (p. 80) states, "the language of human rights has become a principal means of legitimizing political and social agendas” and human rights framing can be used to include or exclude certain norms and policies [9].

Moreover, human rights issues are not static: some issues that have long been accepted as part of a given culture have now become known as human rights violations [10]. Because perceptions of human rights issues are closely connected to particular cultural environments, they are consequently highly sensitive topics affecting the formation of public policy and law in the human rights domain [11]. According to Nash [12], human rights are cultural and their meaning essentially contestable. Thus, due to different sets of cultural beliefs, values, and experiences, people have different understandings of what human rights are [13-15].

This can lead to lack of consensus on whose rights should be protected [16]. Dahre [7] even argues that human rights are used to justify particular cultural, moral, and political views internationally, and can be said to be a form of cultural imperialism. Guttenplan and Margaronis [17] wonder if the distrust between actors will continue, and if human rights agendas can be developed. Donnelly [18] states that there are different views on human rights and that while we are debating which view is correct, the practice of monitoring human rights may be lost. Hence, it is essential to find a common ground on which to base decision-making practices concerning human rights and social inequality.

Governments can draw up treaties and agree to human rights norms, but if citizens are not ready to accept them as legitimate, the support to sustain them will not exist [15]. Thus, both social and political support to legitimize human rights is necessary, as Marsh and Payne [15] argue. Moreover, various forms of power politics between different actors can prevent the creation of solutions. Human rights treaties and agendas may even be used as tool by competing states. Yet, Hafner-Burton et al. [19] argue that repressive states, especially those with greater autonomy, may ratify human rights treaties because no sanctions will be implemented, and ratification legitimizes their policies at a low cost while human rights violations will continue as usual. 
Issue arena theory focuses on public debate concerning social problems in issue arenas that are real, or virtual platforms where the attention devoted to these problems changes over time; the actors may become more or less active and new actors may emerge [20,21]. Many actors strive to participate in the debate and each actor will deploy a framing strategy to enhance the salience of their viewpoints [2]. According to Entman [22] (p. 52), to frame means "to select some aspects of a perceived reality and make them more salient in a communicating text, in such a way as to promote a particular problem definition, causal interpretation, moral evaluation, and/or treatment recommendation.” Framing is classically connected to agenda setting. Originally, the news media were seen as the instigators of framing [23,24]. Currently, while the power of the press is still recognized, other actors, such as political entities and NGOs, also have power as agenda setters and framers [21]. Framing is a tool for impacting other actors' views and engaging them in resolving social issues [25]. It influences what is emphasized in a narrative, and how a story is told. Framing is a selective process, as it stresses certain aspects over others [26]. Therefore, it follows the principles of a zero-sum game [21,27]. If a new social issue draws the attention of the public, then the attention to a previous issue may be lost. In reality, various human rights concerns are constantly being pitted against each other in public discourse [28]. Different issues compete for attention in arenas that have limited carrying capacities, and only the issues which are in some way attractive-for example, have drama attached to them-are rewarded with attention and consequently become salient concerns. Thus the frameworks of various problems actually compete for attention [29]. Moreover, real-world events and other social concerns will act as rivals and possibly influence the attention that will be paid to a social issue. Sometimes a human rights violation is debated in various issue arenas simultaneously as, for example, in national and regional parliaments and in social media. The course of the debate in one issue arena may also influence how the debate develops elsewhere.

In addition to emphasizing certain important aspects of a social problem, the process of framing can also be used in a narrative to connect one issue with another. Linking social concerns to one another in a narrative can have a positive effect, especially when a non-salient problem is linked with a more salient one. For example, linking human rights issues with women's rights has proven to be a powerful framework that has mobilized international support [4]. Nicholson and Chong [30] call this process of linking topics together as "bandwagoning”. Actors will assess the social issue by considering possible linkages between the topic of concern and established human rights concerns [31]. For example, Amnesty generally introduces a new topic by establishing a link with an already established human rights theme [32]. Framing is a strategic process that may also be used to connect one social issue with certain values. Values are essential motivational beliefs about outcomes of favorable modes of individual behavior [33]. If frames do not resonate with the pre-existing system of values and beliefs, then an issue may be disregarded by the public [21]. A value frame thus connects a certain social issue with established values that support one view on the issue [34]. Busby [35] states that to persuade policy actors to become involved in the decision-making process, advocacy frameworks should include values that have a wide societal appeal and personal relevance for the public. Along these lines, Shen and Edwards [36] argue that people bring their own mental frameworks and existing values into the coding process, which adds to the dynamic and selective process of framing. Moreover, they argue that repeated framing of a political problem in a particular manner can eventually influence public opinion. 


\section{Human Trafficking}

Human trafficking has been extensively addressed in the human rights literature. Human trafficking has been described as the cross-border global trading of people in which there is, on one hand, a low risk of being apprehended by state officials and, on the other hand, a high profit margin compared to other illegal activities for the traffickers. Human trafficking usually involves victimizing people through the use of extreme violence and various forms of social, economic, and political discrimination [37-40]. International concern about this problem motivated governments to place this topic on the international agenda in the 1980s and 1990s. Initially, this attention was the result of the feminist protests against violence against women, at a time when international law did not envision human trafficking outside the parameters of prostitution [41]. Political and economic factors and lucrative job opportunities push people from one country, often in the Global South, pulling them to other countries, often Western countries in the Global North [37,42]. Victims are primarily trafficked for sex- and domestic labor-related exploitation, as well as to be victims of forced marriages, to work as beggars, and have their vital organs harvested [38,43]. In an effort to control people so that they may be sold as commodities, traffickers may, for example, drug and abuse their victims [39,44].

Human trafficking has been acknowledged as a very complex issue; it is thus a difficult one to resolve [38,45]. Scholars and political advisors on this serious crime have suggested that, in order to target this problem, the broader socioeconomic context needs to be taken into account [46]. Agbu [38], for example, explains that the volume of trafficking that takes place within a state is connected to the level of corruption in immigration organizations and the number of organized crime networks that are active within a society. Human trafficking networks often operate in conjunction with other illegal trade activities that existed prior to their involvement in human trafficking [43]. Maedl [47] addresses the development of these hierarchical systems in sexual crime, where trafficked women form a so-called "second wave" of criminal activity, when they return to their home country to recruit more victims, thus contributing to further human rights violations. Similarly, victims once trafficked often continue to be trafficked, also demonstrating that human trafficking is part of a cycle of oppression that connects various actors, events, and violations to one another [44,48].

Culturally, scholars describe human trafficking as having deep roots [9]. Perhaps the interrelatedness of specific social problems, and the context in which these problems take place, is not fully understood or agreed upon. Subsequently, understanding what human trafficking is, and how actors and events are interrelated, may be due to culturally bound definitions of what human trafficking is [49]. Thus we contend that it is important to study human trafficking narratives used by human rights and political actors, paying particular attention to the social and cultural contexts that they live in.

\section{Power Politics}

Actors in arenas form various networks. Studies on NGOs by Keck and Sikkink [13] (p. 8) clarify that "networks are forms of organization characterized by voluntary, reciprocal, and horizontal patterns on communication exchange... The network concept travels well because it stresses fluid and open relations among committed and knowledgeable actors working in specialized issue areas.” Moreover, Lewin [50] points out that channels (networks) have no simple beginning and ending, but are circular in character; 
they intertwine, one channel becoming part of another. In issue arenas, power represents a more prominent role in the network. Power can be gained by selecting certain issues to focus on, and through framing and agenda setting.

Many different political actors, including various NGOs, are active in the human rights debate [28], and all have different interests and views to promote in the debate [51]. They battle for power positions armed with their own frameworks and views on what are currently the most salient human rights violations. The causes and effects of these problems are not always shared or agreed upon. Pallas and Urpelainen [52] (p. 6) mention that "in the absence of consensus, power becomes a key issue". Power is more than just Dahl's [53] notion of actor A statically having influence over actor B. Bachrach and Baratz [54] argue there are two faces of power: decision making and non-decision making. During the process of decision making, powerful actors participate and make other actors do something they did not originally want to do, whereas during non-decision-making situations, certain political issues or conflicts are intentionally left out of the discussion [55]. Lukes [56] added that there is a third form of power; ideological power takes place, Lukes argues, when one actor has the ability to manipulate and/or influence the values and points of view of another actor or group of actors. Once an actor has acquired a certain level of power, that actor can then begin to act as a gatekeeper with the ability to influence the course of the debate and, subsequently, the actual decision-making process.

When multiple actors take part in the debate, differences of opinion can create blockages between the actors during the debate and decision-making process, turning the discussion into a political power play. Gatekeeping is a successful form of power politics. Barzilai-Nahon [57] defines it as a process of information control, which can include the selection, addition, and channeling of information; it can also include withholding, shaping, and the manipulation of information, as well as the repetition, localization, integration, disregarding and even the deletion of information. Lewin [50] (p. 145) is credited with developing the notion of gatekeeping, which has since been adopted by various disciplines. He argues that coalition forces in and outside of the gated region decide who is "in power" during the decision-making process and who is "not in power". Bob [28] states that most gatekeepers are organizations with a good staff, a good budget, and a high level of credibility. These powerful actors have the ability and the means to give a certain level of visibility to their favorite issues [28,31]: "Central hubs wish to remain central hubs and prefer to be seen as leaders within a network rather than followers" [31] (p. 98). In addition, Bob [28] (p. 8) claims that "when gatekeepers adopt the claim as a rights issue, the right becomes a recognizable issue on the international scene."

The distribution of power, the position of the actors and their resources thus permit some to become gatekeepers, while others must continue to follow their lead in order to continue receiving support for their own agendas [58]. According to Barzilai-Nahon [57] (p. 1500), information control is connected to power, although "the ability to produce information may produce power, but it is not synonymous to power, and therefore a separation of these constructs (political power and information production) is important." She also states that gated agencies can have power in relation to the gatekeeper, if they exhibit a combination of four attributes: a degree of their own political power, the ability to produce information, a good relationship with the gatekeeper, and alternatives in the context of gatekeeping. Thus gated actors can, via content production, control of agendas and frames, relationship building and producing alternatives, change the course of a debate and influence power relations in different issue arenas. Moreover, to gain issue ownership and power, "issue handling competence is the key" [59] 
(p. 847), which entails the intelligent case by case use of power. With the clever use of information and other means, gated actors may be able to break existing power structures in issue arenas.

Moreover, the fragmentation of coalitions and tension within groups, as well as the forced reality in which the gated actors must comply with the gatekeeper's narratives, can lead some actors to form competing networks and alliances [58], subsequently challenging the central hub and its power relations. Similarly, if a discussion takes place in one issue arena, such as in a national or in the EU parliament, then a counter-debate can occur in online media. For example, victim narrative videos have proven that the social media can create opportunities to disseminate information on important social issues that rarely get attention in the traditional mainstream media, though this in itself does not promise that there will be any political change [60,61]. Therefore, the innovative use of communication tools can also lead to changes in the distribution of information. For example, NGOs' use of social media to inform the general public about human trafficking may lead to the transfer of the debate about this problem to a parliamentary context. It is important to understand how different actors discuss human trafficking and to what extent they emphasize certain criteria while they are framing the issue, as it is clear that shared opinions about this problem may facilitate the development of global norms and solutions.

\section{Research Methods}

The aim of this paper is to clarify how human trafficking is discussed, by focusing on the work that is undertaken by two human rights organizations, Amnesty International (Amnesty) and Human Rights Watch (HRW), in addition to the European Parliament (EP). These actors were chosen because they are well-known international NGOs that participate in the development of public policy and law formation. The EP is actively engaged in discussing the topic of human trafficking and finding solutions to this international problem. The research questions that these data address are: (1) In what context is trafficking discussed by the three actors? (2) How do these actors frame the definition of human trafficking in their presentations?

To answer the research questions, a selection of documents was completed and further analyzed. The content analysis took five months to complete. It started at the beginning of January 2013 and finished by the end of May 2013. The dataset includes the two calendar years, 2011 and 2012. Initially, this research inquiry yielded 2225 documents and research reports from Amnesty and the HRW and 168 decision-making documents from the EP. Using a thematic analysis, we examined these documents, identifying those that discussed the topic. Our sample frame then yielded a total of 240 documents that were then further analyzed to see how the issue of human trafficking was addressed by the actors.

The individual documents were analyzed in a similar way. After studying all of the documents, three long data extraction tables were compiled, for the sources of Amnesty, Human Rights Watch and the European Parliament. During the first reading of the document, the title of each document was copied into the table along with the date of publication and reference number, if it was available. This was done to facilitate the retrieval of the document for further examination. During the second reading of the document, direct citations about human trafficking were underlined in order to return to them later during the analytical stage of the research process. Direct citations about human trafficking were then copied into the data-extraction tables. After the third reading of the document, all the citations that were about bandwagoning were also copied into the data-extraction tables under each document title, to create 
an overview of the narratives addressing human trafficking, the various frameworks that were used, and the numerous references to bandwagoning that were recorded.

First, data was drawn from documents that represented the two NGOs that we were studying. To find all the documents that were written in English, we used the website address from their official websites to locate them $[62,63]$, The structured search was done by using the keywords "human trafficking” and "trafficking of/in [humans]." The latter set of key words was included as it is often used as a synonym for human trafficking.

The timeframe for the research study was a two-year period beginning on 1 January 2011 until 31 December 2012. The material that was used in our analysis was selected using these three main criteria. The first criterion was that the document had to be created during the two-year time period of 2011 and 2012. Second, the selected materials had to include either the term "human trafficking” or "trafficking of/in humans." The third criterion was that the selected documents had to include at least one sentence about human trafficking, because a simple two-word mention of human trafficking was not deemed as providing real data for answering the research question. Documents that only mentioned the words "trafficking" or "human" were excluded, since they did not cover human trafficking as an action or social phenomenon, but discussed other matters such as drug trafficking or weapon treaties. A total of 730 documents that fit our criteria were found in the Amnesty reports, and 1495 documents were found among the HRW documents. After selecting the text fragments from these documents, the data-extraction table for Amnesty amounted to 53 pages of transcriptions from a total sample of 96 documents, and the HRW table generated 67 pages of quotations from a sample of 122 documents.

A similar analysis of the documents of the European Parliament was then carried out. The EP data collection started in February 2013, and it had a longer three-year timeframe, spanning from 1 January 2010 to 31 December 2012. Although we focused our analysis on the documents that had been discussed in 2011 and 2012, the research period had to cover a period of three years for the documents of the EP, as the preliminary preparations for topics that were debated in the parliament hearings in 2011 or 2012 had begun in 2010. This is due to the fact that preparation for debate and decision making to take place takes time and, especially at the parliamentary level, multiple experts such as university professors, government officials, representatives from NGOs, members of interest groups and other organizations are all heard in the preliminary sub-committee meetings which are convened prior to the debate and decision-making stages.

The EP's documents were found on the European Parliament's Legal Observatory website [64]. The first criterion was that debate had to fall within the three-year timeframe that we had selected. The same key words as we used while analyzing the NGOs documents were used: "human trafficking", "trafficking in [human]" and "trafficking of [humans]." An additional criterion was added in that for each English-language PDF document, the labels "Procedure completed" and "Text adopted by Parliament, 1st reading/single reading", which meant that the document was a final product of a political discussion and the subsequent decision-making process, had to be present. The third criterion was that each document had to clearly mention human trafficking. Thus the search key words had to be mentioned along with at least one sentence about human trafficking, as in the analysis of the documents of the NGOs. Altogether, 168 documents were found using this research method, and 50 documents matched all the criteria. After discarding duplicate documents, 22 separate documents remained and they were included in the analysis. This resulted in a data-extraction table of 51 pages. In our analysis, we 
examined narratives that focused on bandwagoning issues. We did this so that we could then determine whether bandwagoning was linked to the narratives. In addition, the different ways of framing the issue of human trafficking and how this increased its salience as an important political issue were also noted.

\section{Results}

First, the findings for the two human rights organizations are reported, followed by the findings for the EP. The actor's narratives are summarized with an emphasis on the context where trafficking is discussed and on the framing of trafficking and possible connected issues.

\subsection{Amnesty International and Human Rights Watch}

Amnesty International (Amnesty) and Human Rights Watch (HRW) have both extensively reported on human trafficking in many documents that their organizations produce. The main finding of this study is that human trafficking is not discussed as an isolated issue, but it is connected to many other serious social problems such as rape, labor violations, sexual exploitation, kidnapping, prostitution, blackmail, governmental corruption, ill treatment or abuse and murder. Women and children were the most commonly reported victims of trafficking networks as they are frequently exploited as workers and sexual slaves. Moreover, some of the documents emphasized that people are increasingly trafficked for the illegal global organ trade, and children especially are kidnapped or coerced into being used as soldiers. Therefore, the topic of human trafficking does not stand alone in the reports of the NGOs but is discussed in the wider context of various other human rights violations; it is consequently framed so that it is closely connected with these other serious crimes. Various types of framing which are discussed in the human rights literature are found in these documents [21]. In the sample derived from the documents of HRW and Amnesty, Amnesty in particular used a strategy called "framing of responsibility." This is a framing strategy that draws attention to the root causes of trafficking: global poverty, gender inequality, and the lack of political will to resolve this human rights issue. Furthermore, the NGO points out that human trafficking is often closely linked with government and security officials, as well as with policy-making practices.

According to the NGO's reports, people who become trafficking victims are individuals who usually have lived in poverty, and may have experienced a violent home life that generated distress. For people who are living in these conditions, the idea that they could make a lucrative living abroad gives them hope that their quality of life will improve. Instead these people are being sold as slaves who work in horrendous conditions with little or no pay. The profit from their work is taken by the traffickers and subsequently their potential earnings and the good jobs that they were promised in other countries turn out to be empty promises. In the documents on human trafficking, both Amnesty and HRW bandwagon various forms of exploitation that domestic migrant workers in particular face worldwide. These issues include excessive working hours, forced labor, non-payment of wages and forced debts, involuntary confinement, physical and sexual abuse, and trafficking: "Migrant workers faced exploitation by recruiters who exposed them to human trafficking and forced labour” [65]. In the documents, HRW and Amnesty report that trafficking begins in situations where migration is an attractive option for people who, due to poverty and violence in the home country, seek a better life or money to support their family back home. Before leaving for their new destination, immigrants are commonly required to sign 
documents such as employment contracts, though the immigrants often do not receive any copies of the signed documents. Upon arrival in the receiving country, the migrant laborers' passports are taken away and their movements are monitored and restricted by the traffickers. Amnesty's documents report that migrant laborers are deceived about their terms and conditions of work, including their rate of wages and their entitlement to rest days or holidays. Many migrant laborers end up as "trafficked" due to the fact that they often take out loans of money from the "employment agencies" so that they can travel to work in another country. Due to the low wages that they earn, they are unable to pay back their debts and end up living in debt cycles beholden to the employment agencies. Often, migrant workers have to give most of their salaries to their recruiters to work off their debt, causing them additional poverty, debts and subsequent reliance on both the work they are given and the agency, which causes additional human rights violations. The NGOs argue that local and regional officials often disregard these abuses and allow the exploitation of these workers to continue. This illustrates how this serious social problem is interrelated with global poverty and continued financial dependency. The root causes for trafficking, such as poverty and illegal immigration, are problems that are often not addressed in the workers' countries of origin.

According to the NGOs, recruiters and employment agencies are part of trafficking networks that cooperate or have ties to state and security officials that allow, facilitate, and profit from human trafficking. In one document, HRW claims that governmental officials in Eritrea are directly taking part in human trafficking. Military officers charge US\$3000 per person to arrange for their escape from the country, whereas smugglers associated with the military forces demand additional ransom fees of up to US\$20,000 to release the escapees for their onward journey. HRW claims that the ransom is then sent to the Eritrean embassy staff in Cairo, and the money from smuggling and ransom fees is deposited into a Swiss Bank account. HRW claims that these substantial profits may actually lure government officials into taking part in human trafficking. In numerous documents from Amnesty and HRW, they report that state officials have been aware of or have taken part in trafficking and labor exploitation networks in Cambodia, Jordan, Malaysia, Thailand, and Uzbekistan, as well as between countries in South and North America. According to many of the HRW and Amnesty documents, human trafficking is controlled by competing drug cartels receiving protection from political proxies and expand their criminal activities in drug trafficking to include human trafficking. Amnesty has numerous documented cases where people are trafficked to the USA to work as sexual slaves. Sexual slavery includes forced sex work in the commercial sex industry, street prostitution, and work in massage parlors and brothels. Other forms of slavery include domestic service work, agricultural labor, construction work, hotel services, manufacturing and healthcare jobs. In some documents, HRW points out that victims of human trafficking are held in immigration detention centers in the USA. Due to their fear of deportation, migrant workers are often afraid to report these crimes to the police.

According to both NGOs, poverty clearly plays an important role in the exploitation and trafficking of humans globally, but it is not the only factor in play. Human trafficking is closely connected to other forms of exploitation and ill treatment, such as gender violence, which stems from stereotyped gender roles, and child labor, as evidenced in the documents. Amnesty reports that in Chad, "some of the girls are pushed by their parents to go and look for jobs in the cities and towns, while others are 'sold' by their parents to individuals known to their families or even to strangers" [66]. Similarly, HRW reports that in Mali in the mining industry, children are trafficked and exploited extensively. Some children come from 
neighboring countries such as Burkina Faso and Guinea. HRW claims that child labor is common in Mali and other parts of West Africa, since, owing to extreme poverty, child labor is a common strategy for families to make money, while they are simultaneously exposing children to abuse and denying them the right to an education. HRW points out that although the Malian government has taken steps to handle human trafficking and child abuse, the ability of the government to tackle and prevent these violations is limited. Human trafficking is thus described in the documents as a chain of interlinked events that includes brokers, agencies, and state officials.

Amnesty reports that in Afghanistan women and girls suffer from a wide range of violations, such as being traded to settle disputes, gender discrimination, domestic violence, forced marriages and trafficking. In a similar manner, HRW explains in its documents that the trafficking of women and girls from Iraq for sexual exploitation is widespread, while militias and religious and government institutions that take part in the various forms of exploitation promote misogynist ideologies. In one document, Amnesty recounts one woman's narrative. The woman was trafficked, spent months in captivity in a brothel, and was later refused the right to have an abortion in Argentina. A similar trend is found in Nepal. HRW's documents tell us how, even though they have legal rights on paper, women and girls still face widespread discrimination. Trafficking, domestic violence, dowry-related violence, rape, and sexual assault are serious problems not followed up by effective police investigations.

HRW also reports that when tackling the ongoing problem of helping the victims of human trafficking, well-meaning governmental authorities often use ineffective methods of support. HRW mentions that victims did not know about the hotlines that were set up by a labor ministry, and that usually the hotlines did not work, or that there were no qualified interpreters available to help them understand what their rights were. Amnesty claims that in Sierra Leone, for instance, victim support systems are not guaranteed by the law, thus only NGOs organize support for victims of trafficking, and sexual and gender-based violence. Both HRW and Amnesty report that a police crackdown on human trafficking usually consists of closing down brothels and randomly detaining sex workers instead of actually prosecuting the traffickers. HRW mentions that a department that was supposed to be fighting human trafficking in the Ukraine was actually exploiting women who were working as sex workers on the highways of Ukraine. Moreover, for government officials, the line between lawfully employed migrant laborers and trafficked people is not always clear. Amnesty reports that victims of trafficking and torture have been detained in Denmark and the Netherlands, as they are considered illegal immigrants. Both Amnesty and HRW emphasize the fact that trafficked people often are not recognized as victims. For example, in Finland, victims of prostitution-related trafficking are treated as witnesses, and thus denied victim assistance and support benefits, and they usually face deportation. Other examples of the denial of assistance for victims was documented by HRW, claiming that victims of trafficking make their way to e.g., Cairo and then gain access to some victim services. However, the Egyptian government refused the United Nations High Commissioner for Refugees (UNHCR) access to the refugees, and asylum seekers and migrants were intercepted and detained in Sinai. Egyptian officials asserted that they were economic migrants and Egypt therefore had no obligation to give the UNHCR officials an opportunity to speak to them. These same officials have also ignored the horrific abuses committed against asylum seekers and migrant laborers in Sinai. Similarly, both Amnesty and HRW describe how human trafficking is a widespread problem in the Mediterranean region. Since joining the EU, Cyprus has become a destination for migrant laborers and for the trafficking of women for sexual 
exploitation. Additionally, Amnesty reports that several European countries, such as Malta and Italy, have refused to allow private vessels, e.g., fishing boats, carrying traumatized migrants and refugees from international waters to enter their territory "until there is a political agreement on where they can go”. Moreover, the “desire of some European countries to prevent 'irregular migration' is undermining safe and timely rescues at sea" [67]. HRW also noted that the Mediterranean region is a heavily trafficked area, as is the Sahel region. Some Mediterranean countries, such as Italy and Greece, do not have adequate systems to screen and aid victims of trafficking. According to HRW, migrant laborers who were travelling to Italy in non-seaworthy vessels were returned to Libya. None of the refugees were consulted by officials, rendering sick, injured or pregnant persons, in addition to unaccompanied children and victims of trafficking unprotected and without refuge. HRW is concerned that most of the unaccompanied children brought to Greece as migrant laborers often end up living on the streets. These children are at risk of being trafficked as they are vulnerable populations likely to be subjected to labor exploitation, prostitution and drug trafficking. HRW reported that in 2011 the UN special rapporteur called the conditions of Greece's immigration detention facilities inhumane and degrading. Ineffective or corrupt governmental officials, gender-based violence, and extreme poverty are root causes of human trafficking. In some countries, these issues are exacerbated by a lack of border security and power struggles between vying elites or militias. HRW and Amnesty documents are heavily focused on the human rights situation and widespread trafficking of mostly sub-Saharan migrant workers and asylum seekers in the Sahel and Sinai areas. Amnesty claims that "there is an extensive network of people-traffickers throughout Eritrea, Ethiopia, Sudan, Egypt and Israel. The traffickers are both well-equipped and well-armed. Hostages are sold between groups at country borders. Ransom money is extorted from relatives or communities and is reportedly often paid in Cairo, Tel Aviv, and Asmara, and can reportedly run into thousands of US dollars” [68]. The hostages are tortured, sexually assaulted, and raped in order to coerce their relatives to pay their ransom fees. In one document, Amnesty mentions that "foreign nationals have reportedly been held, tortured, including raped, and murdered by people-traffickers, while the authorities have done little to protect them” [68]. Similarly, HRW states that due to an absence of law enforcement, "thousands of sub-Saharan asylum seekers and migrants attempting to cross the Sinai have fallen victim to abusive traffickers and other criminals" [69]. Traffickers imprison victims and then demand a ransom from their families. According to HRW, those who cannot pay for their ransom are forced to pay the debt back to their captors by working. HRW estimates that that the traffickers' demands for money has risen from US\$2500 US\$30,000 USD per person between the years 2009 and 2012. HRW reports that while victims are on the phone pleading with their relatives at home or abroad to pay their ransom, the traffickers often torture and beat them. Thus, the torture of African asylum seekers, refugees and migrant workers has increased since 2010. In one document, HRW substantiates reports about traffickers torturing and abusing people. In one witness's testimony, she reported that up to 100 trafficked people at a time were taken into "stores" where large numbers of Eritrean, Ethiopian and Sudanese victims were kept: "They were chained at the feet and tied or chained at the wrists. Access to food and water was inadequate and beatings were frequent” [69]. NGOs report that women were raped and sexually abused, traffickers groped them and penetrated them with their fingers, and some had burns on their breasts and genitalia. Some victims were beaten on their hands, and on the soles of their feet and backs with metal rods. They were also blindfolded and chained, burned with cigarettes or by molten plastic from water bottles, kicked and punched. Men and women 
also were sexually assaulted by being stripped and plastic piping inserted into their anuses or vaginas. Amnesty reported that they have learned of the same human rights violations and extortion methods, adding that trafficked people are "being subjected to electrical shocks, deprived of water for extended periods of time, and tied to trees for extended periods in desert heat” [68].

In addition to torture and extreme sexual violence, Amnesty adds that traffickers forcibly remove organs surgically from victims and sell these harvested organs on the black market, while the victims most commonly die, either during or after the surgery. By discussing this issue, Amnesty draws attention to another context of human trafficking by connecting it to the organ transplant tourism industry. Moreover, Amnesty states that organ trafficking with transplant tourism violates the principles of equity, justice, and respect for human dignity. "Because transplant commercialism targets impoverished and otherwise vulnerable donors, it leads inexorably to inequity and injustice and should be prohibited” [70]. Amnesty calls for states to prevent organ trafficking, framing once again state responsibility.

The various examples of narratives that have been selected from the NGOs' documents illustrate how deeply rooted social practices and prejudices can contribute or even lead to human trafficking. These narratives also show that human trafficking must be understood within a broader global context and that several human rights issues are interwoven into the NGOs' documents. Both Amnesty's and HRW's documents illustrate that in addition to global poverty, gendered violence, insecure borders, and the poor functioning of juridical systems exacerbates these human rights violations. Thus, in order to tackle the problem of human trafficking, the root causes of why people are seeking work has to be addressed within the context of the various, political, social, economic, legal, and cultural environments in which they live.

\subsection{European Parliament}

In this section, the results from the analysis of the European Parliament documents on human trafficking are presented. There are not many documents of the EP that discuss human trafficking in our research sample; however, when the EP did address this issue, it was covered extensively. Many actors were consulted and human trafficking was discussed in the context of several other social issues.

Each document in our study addressed several topics and they are recorded on each document. (The eight-digit code number functions as a reference. The documents can be found online at the Legal Observatory website of the EP.) There are altogether 33 different topics or subject areas found in the 22 documents that comprise our sample. These subject areas present various aspects of the EP's decision-making process and provide a preliminary view of how the EP creates the political context in which decision making takes place.

The most frequently cited subject areas of the EP are: (1) Women's condition and rights; (2) Gender equality; (3) Work, employment, wages, and salaries: equal opportunities for women and men, and for all; (4) Fundamental freedoms, human rights, democracy in general; (5) Bilateral economic and trade agreements and relations; (6) Emergency, food, humanitarian aid, aid to refugees; and (7) Candidate countries.

According to the frequency that the subject areas are cited, human trafficking is strongly connected to gender equality and women's rights, equal opportunities between the sexes, fundamental rights and freedoms, and general concepts about democracy. Moreover, economic and trade relations, 
humanitarian and aid issues, and the enlargement of the EU are all connected to social problems that facilitate the development of human trafficking rings. After scrutinizing the content of these documents, a more comprehensive picture of the social context in which human trafficking arises can be found.

The documents of the EP address the problem of human trafficking by describing it as an issue that effects the world community as it is related to gender-based violence and to the economic or labor market situation in the world today. Gender-based violence is defined by the EP as "a form of discrimination and a violation of the fundamental freedoms of the victim and includes violence in close relationships, sexual violence (including rape, sexual assault and harassment), trafficking in human beings, slavery, and different forms of harmful practices, such as forced marriages, female genital mutilation and so-called 'honour crimes'” [71]. With respect to the economic or labor market situation, the EP argues that “male violence against women shapes women's place in society: their health, access to employment and education, integration into social and cultural activities, economic independence, participation in public and political life and decision-making, and relations with men” [72]. The EP states that "Victims of human trafficking are mostly women and girls" [73] and they are treated as modern commodities to be sold and re-sold, thereby directly affecting the equality between women and men in society. Human trafficking is a lucrative business run by organized crime syndicates with international networks, along with other forms of trafficking such as gun and drug/tobacco trafficking. According to the EP, trafficked women are in danger of being marginalized by the society in which they live. The EP states that "women face multiple forms of discrimination and are more vulnerable to social exclusion, poverty and extreme human rights violations, such as trafficking in human beings, especially if they do not belong to mainstream society" [74].

Moreover, similarly to the two NGOs' positions on human trafficking, the EP mentions that victims of human trafficking should not be treated as criminals or refused support. The EP mentions its deep concern regarding the media reports about victims of human trafficking being treated as criminals instead of getting support, consequently calling for the EU Commission to investigate the treatment of victims of trafficking, sexual slavery, and forced prostitution in EU states. The EP states that human rights for women should be given the highest priority in European external policies and calls for "the implementation of Directive 2011/36/EU on preventing and combating trafficking in human beings and protecting its victims” [74]. In many documents, the EP mentions looking forward to the results of systems put in place for monitoring transparency and financial fair play and combating corruption and human trafficking.

Moreover, the EP requests that EU states “acknowledge the serious problem of surrogacy which constitutes an exploitation of the female body and her reproductive organs" [72]. Exploitation, commodification, and coercion can be involved when women have a baby, as an example, for wealthy parents. Furthermore, the EP "recognizes the serious problem of prostitution, including child prostitution, in the European Union, and requests further studies into the link between the legal framework in the Member State in question and the form and extent of the prostitution taking place; draws attention to the worrying increase in human trafficking into and within the EU-A trade which targets women and children in particular-and urges Member States to take firm action to combat this illegal practice” [72].

Besides reproductive markets, the EP addressed the problem of illegal adoption in the EU by stating that children are trafficked for adoption, begging, forced marriages, illegal labor, prostitution and other 
purposes. In addition, the EP emphasizes that gender-based violence in particular makes migrant women, including undocumented migrant laborers and asylum-seekers, vulnerable. The EP sees that too often gender-based violence is allowed to continue, by being hidden and undocumented, while it is affecting many families and influencing the lives of children as well.

In some documents, the EP focuses on certain service sectors, such as massage parlors and saunas. The EP calls for an end to all the forms of harassment that workers can experience in the service sector and these forms of harassment include: "economic violence, psychological and sexual workplace harassment, sexual abuse and human trafficking” [75]. The EP asks member states to tackle exploitation in the service sector and to fight against the criminal networks that control these services. In addition, they encourage member states to provide victim support services to those in need.

Looking at human trafficking in a broader context, the EP notes that human trafficking in connection with various other crimes can contribute to the widespread devastation of societies, especially in the Sahel-Saharan and Sinai regions. In EP documents, links are mentioned between, for example, terrorist groups in the Sahel-Saharan region and traffickers in drugs, arms, cigarettes and human beings. They report that: "State fragility, poor governance and corruption in the Sahel countries, accompanied by economic underdevelopment resulting in chronic poverty, provide a perfect environment for terrorist groups, drug and human traffickers, and groups engaged in piracy, arms trade, money laundering, illegal immigration and organized crime networks, which combine to destabilize the region, with a negative impact also on neighbouring regions” [76]. This places the issue in the context of various other crimes, which is a similar conclusion drawn about Amnesty's and HRW's documents.

Due to food shortages, people seek food, work, and shelter elsewhere. The EP notes that: "Sahel is facing its worst humanitarian crisis in the past 20 years... a major humanitarian crisis may develop which could also have a negative impact on neighbouring countries" [77]. Consequently, the lack of: economic development, social justice, implementation of laws and economic prospects, causes despair and extreme poverty among displaced people, which can then lead to terrorism or the trafficking of vulnerable populations which usually includes women and children: "Sexual violence appears to be being used as a way of intimidating and degrading women, including in refugee camps, whereas the power vacuum that has emerged can lead to deterioration of the rights of women and girls” [78]. The EP reported cases where people were being kidnapped by traffickers in Sudan and brought to Sinai, "thousands of asylum seekers and migrants lose their lives and disappear in Sinai every year while others, including many women and children, are kidnapped and held hostage for ransom by human traffickers, victims of human traffickers are abused in the most dehumanizing manner and are subject to systemic violence and torture, rape and sexual abuse, and forced labor” [79]. The EP urges the EU Commission and its member states to do something about the situation of women and girls in the Sahel region and to take all the necessary action that is needed to protect them from violence and human rights violations.

Also, the EP notes that: "irregular migrants are detained in Sinai and Upper Egypt without access to UNHCR and thus are denied the possibility of making asylum claims” [79]. While it acknowledged that work already is being done by Egyptian and Israeli officials to resolve this problem, the EP urged the two countries to provide help and assistance to victims of human trafficking in Sinai. The EP has especially called upon Egypt to implement the anti-trafficking law of 2010 along with other national and international laws in order to tackle the problem of human trafficking, and to allow UN agencies access 
to places in Sinai affected by trafficking. “The EP urges the Egyptian authorities to take all necessary measures to stop the torture, extortion and human trafficking of Eritrean refugees and other refugees in the country, and to prosecute those who attempt to violate refugees' human rights and those who practice any form of slavery, with special regard to women and children” [79]. However, the EP did applaud the "activities of Egyptian and Israeli human rights organizations, which provide assistance and medical treatment to victims of human traffickers in Sinai," saying said that "human rights NGOs and UN agencies should have access to areas affected by human trafficking in Sinai, and urges the international community and the EU to support their work” [79]. Thus, in the EP's documents, many correlations, especially with state authorities and UN agencies, were made.

The EP only addressed one case study of human trafficking in one document, which was linked to human trafficking in Sinai. The EP called for the protection of a young man called Solomon W, since he was one of the traffickers' victims and human organ traffickers had put a price of US\$50,000 on his head because, as a witness he was the "only survivor, [and] knows exactly where the prisoners are kept and he also witnessed the murders, tortures and rapes" [79]. The EP reports that "the Eritrean young man revealed that one of the jailers showed him a plastic bag containing human organs of a refugee who did not pay the ransom” [79]. In some cases, the documents show anticipative action. The EP asked the Council and the EU Commission to propose assistance to Libya, with the support of the UN and other international expert agencies. This support would be aimed at "addressing the problem of trafficking of human beings in the region, with special attention to the protection of women and children, including assistance to integrate legal migrants and to improve conditions for migrants found illegally in the country" [80]. The EP noted that the conflict in Libya had increased the demand for arms in the Sahel-Saharan region, and that this new development will place greater profits of money, into the hands of numerous terrorists and drug traffickers, who will then use this money to engage in other serious crimes in the region.

The EP noted that the trafficking of persons for labor exploitation continues to be widespread in the United Arab Emirates and victims of this form of human trafficking usually "remain unidentified" [81]. Indeed, the vast human rights violations in Central Asia were addressed by the EP. Although there is "strong political and economical interest to strengthen bi-multilateral relations with Central Asian countries," the EP nevertheless "calls for respect of universal values such as human rights and names common challenge and threats: border management, drug and human trafficking” [82]. The EP asks the EU to focus its assistance on combating drug and human trafficking, which it sees as the major reason for instability in Central Asia. Moreover, the EP argues that the right to an education is linked to human and civil rights, access of women to the labor market and the promotion of human rights and tolerance among young people. The EP also noted that NGOs must have the possibility to operate freely in the area, and it condemns the Uzbek government's decision to close down the HRW office. Here, the EP explicitly referred to the role of NGOs in the region and it also commented on human trafficking as a problem in the Black Sea area. It argues that "cross-border crime and trafficking, in particular in drugs and human beings, and illegal migration to be tackled in the Black Sea Strategy, also calls for a further strengthening of cooperation on border and movement management” [83]. As a main objective, the EP stressed that the Black Sea Region should seek to "establish an area of peace, democracy, prosperity and stability, founded on respect for human rights and fundamental freedoms and providing for EU energy security" [83]. 
On many occasions, the EP noted that internationally there are very low levels of gender equality. EP documents reveal that in Afghanistan and Pakistan women and girls experience acid attacks, domestic violence, trafficking, in addition to forced and child marriages, while the police seldom address women's complaints. The EP noted that police forces are often involved in kidnappings, rapes and murders of women. Because Pakistan's laws are discriminatory, and the application of some laws, notably family laws, can result in women's human rights being violated, the EP has been urging Afghan authorities not to follow suit and ensure that the police, courts and justice-sector officials follow up on women's complaints of abuse, including beatings, rape and other forms of sexual violence. It also notes that many of the violators remain unpunished and that certain laws, e.g., family laws, lead to extensive violations of women's rights. The EP proposes that democratic development in Afghanistan and the respect for women's and others' rights go hand in hand, and it expresses concern, especially about women being controlled by the Taliban's social codes. In this way, human trafficking and other violations are discussed in connection with legal and ethical problems that are specific to Afghanistan and Pakistan.

In the European context, the EP notes that asylum seekers from Serbia are trafficked to EU member states. The EP therefore calls for the EU to cooperate in combating the links between false asylum seekers and human trafficking, and to fight against organized criminal groups involved in human trafficking. The EP is also "seriously concerned about the role played by Kosovo organized crime in various criminal activities in the region, involving drugs and trafficking in human beings” [84]. The EP and both NGOs urge Kosovar and Albanian authorities to cooperate with neighboring countries and to give their full support to the EULEX Special Investigative Task Force that investigates the inhumane treatment of people and the illegal trafficking in human organs. In one document on the EU's enlargement talks with Croatia, the EP urged the authorities to fight human trafficking in order to become an EU member state, and to develop transparency and equality in their legislative, police, and judiciary processes.

Natural disasters may also lead to the devastation and exploitation of vulnerable populations. The EP also noted the exploitation faced by women and children in Haiti, and expressed concern "about the situation of the most vulnerable groups of people, in particular women and children, in the wake of the earthquake, which has had a huge impact on more than 800,000 children, exposing them to the risk of violence, sexual abuse, trafficking, exploitation and abandonment” [85]. The EP urged Haitian authorities to increase the level of security in refugee camps, and to include Haitians in the process of rebuilding their society. The EP is asking "the international community to use this as an opportunity to tackle the root causes of underlying poverty in Haiti once and for all” [85]. The EP also links fishing to human trafficking, as does HRW. Illegal, unreported, and unregulated (IUU) fishing attracts many illegal activities. The EP "is alarmed at the use of such criminal activities as human exploitation and trafficking, money laundering, corruption, handling of stolen goods, tax evasion and customs fraud by those engaged in IUU fishing, which should be viewed as a form of organized transnational crime” [86]; consequently, the EP asks for more attention at the EU and Interpol levels to fight IUU fishing.

The EP also discussed human trafficking in the context of sports. Whereas the EP sees a place for sports in various sectors of a democratic society and education, it "looks forward to the results of systems put in place for monitoring transparency and financial fair play and for combating corruption and human trafficking; [it] stresses the need for the system to comply with EU law and data protection 
rules” [87]. The EP argued further that any kind of discrimination should be excluded from sport as should political, religious or racist propaganda at sport events and that it should be ensured that women are not excluded from sports due to political pressure. The EP also noted that match fixing and the use of illegal prostitution take place at sporting events.

The documents show that various forms of gender-based violence, social inequality and serious human rights violations are brought together in the EP's political discussions. Human trafficking is part of a large and complex conglomerate of social justice issues. The traditional way of thinking about human rights issues as occurring singly and in isolation no longer applies. Addressing the problem of human trafficking and finding a solution must take into consideration that social issues are intertwined, and framed together. Thus, discussing human rights violations as separate issues in the absence of any broader social-political dimensions seems vastly outdated. According to the EP, grassroots participation by NGOs is essential for solving issues such as human trafficking and gender-based violence, as is utilizing the skills of women in problem-solving and conflict resolution. The EP urges EU authorities to put all forms of human rights at the center of EU foreign policies and take into consideration the broader geopolitical context.

\section{Discussion}

In the debate on human trafficking by Amnesty, HRW and the EP, this study found evidence concerning the context in which trafficking is discussed, how interrelatedness of issues is seen, causal relations are framed, actors compete for attention, actor networks are formed and issue transfer takes place. These characteristics will be further discussed below.

\subsection{Interrelated Issues}

Various actors such as NGOs act as advisors and decision makers, and take part or seek to take part in the debate on policy and law formation that addresses human rights issues. Therefore, it is important to see how, as established political actors, the two well-known NGOs and the EP discuss and frame human trafficking, and to see what context they place it in. Opening up the context in which this issue is debated can help clarify our understanding of why the decision-making process that addresses human rights issues can be such a long one. It is as important to understand the framing in the debate that occurs prior to the final decision making as it is to understand the final endgame during the decision-making stage.

During the two-year observation period from 2011 to 2013, human trafficking was addressed to varying degrees by the two NGOs, Amnesty International and Human Rights Watch, as well as the European Parliament. Based on our findings from our research, we propose that trafficking was generally discussed within a broad context and it had complex connections with various other social issues. The NGOs discussed human trafficking primarily by addressing it and then connecting it to other issues, whilst the European Parliament primarily discussed other issues and then attached human trafficking to these issues. This shows that social issues are intertwined by the broad and complex connections to other issues. Thus, viewing human rights violations as a separate issue without connecting it to any broader social-political context is an outdated notion.

For the EP, human trafficking is part of the larger context of gender-based violence that hinders the development of societies in Europe and throughout the world. The EP stated on several occasions that 
the problem of human trafficking was recognized, while also admitting that the problem remains largely unresolved. Based on the present results, the EP saw the victims of human trafficking as mostly women and girls, a notion shared by both Amnesty and HRW. The EP connected human trafficking to various forms of sexual exploitation and rape, honor crimes, slavery, surrogacy, illegal adoption, work life and societal inequalities, as well as to several harmful traditional practices, thus creating a hotbed of multiple interrelated violations. For Amnesty and HRW, the most common connections with human trafficking were rape, labor and sexual exploitation, kidnapping, prostitution, blackmail, corruption, and ill treatment and murder. The EP saw the problem as primarily a concern about the sale of women and children as modern commodities for various kinds of exploitation, including prostitution, labor, illegal surrogacy, forced adoption and the use of their bodies for the organ market. The two NGOs had similar concerns in their documents. They emphasized the context in which people are trafficked for work and sexual purposes. The NGOs have consistently reported that large numbers of people's bodies are harvested for organs and children are forced to work as soldiers.

The documents also revealed some unusual connections, in particular between trafficking and illegal fishing, and with European-wide sports policies. This illustrates that the social problem of human trafficking and human exploitation in its various forms is sometimes deeply rooted in everyday life and is often hidden from our view.

\subsection{Framing and Causal Relations}

All the actors framed the issue of human trafficking in connection to other issues. They all stressed the causal relationships between human trafficking and other serious social problems. This enhanced the understanding of the broader issue clusters that emerged and supported the creation of social policies and laws. According to the documents of the EP, human trafficking has deep roots, which include extreme poverty, social inequality, a lack of basic human rights, poor governance, state fragility and corruption, along with economic underdevelopment and the effects of climate change. Subsequently, these social variables in diverse combinations have created a basis for organized crime and hence traffickers of humans, gun, drugs, money laundering, and illegal immigration to flourish. Moreover, severe drought and food and fuel crises have contributed to the increase in human trafficking by creating not only displaced and unemployed populations searching for work, but also unease, political power vacuums, and destitution in many countries.

Amnesty and HRW have emphasized that the problems of poverty and gender inequality, corruption among government and security officials, obsolete juridical systems and the lack of political will are the underlying causes of human trafficking. Finding a solution to this multi-faceted problem base is a challenge. However, as the results show, trafficking does not occur just because people are poor; rather, trafficking should be seen as one part of a cycle that is the exploitation of people. Thus, to tackle human trafficking, the issues related to it must be framed as important and then thoroughly addressed. A societal problem of this magnitude needs to be understood in terms of the multiple related issues that they are connected to. The framework that has been constructed to explain the connection between human trafficking and other social issues, therefore, has ensured that these problems have also become salient issues in the public debate. 
Human trafficking is not the end or the beginning of human exploitation. Often, various actors take part in the cycle of exploiting people, creating hierarchical structures in trafficking networks [47]. The EP mentioned various subgroups, such as people without state documents and asylum seekers, as vulnerable to exploitation and trafficking. The EP also claimed that the victims of human trafficking are being treated as criminals and thus denied support, exposing them to danger and possible re-victimization. Both NGOs also concur with this notion, stressing that protocols for victim recognition and support services are essential. The EP also noted that there is a need for training officials to offer good-quality support services and to be able to break the cycle of repeated victimization.

The connections made in the documents by framing issues and actors together in a particular context often suggest a causal relation and indicates that there is a chain of events leading to exploitation and (re-)trafficking. This way of drawing attention to cause and effect is known as responsibility framing [21]. The causal relationships that the actors have developed and possibly even the attribution of blame, indicate directions for proposed solutions. In the public debate, the measures taken need to be explained and connected to values. Based on the results, the EP, Amnesty and HRW gave examples of the strong causality between other issues and trafficking, building communicative frames around the causes and effects, while adding factual but at the same time emotional narratives about how victims are mistreated. This invites people to see such connections, subsequently adding issue salience $[34,35,56]$. The actors used naming-shaming frames to point to those responsible for illegal acts or those who refrain from corrective action. By utilizing framing, Amnesty, HRW and the EP point to criminal networks, but also claim that the actions or non-actions of authorities can cause, harbor, and contribute to human trafficking and various other violations, in turn affecting policy and law formulation.

\subsection{Competing for Attention}

Human rights are political and discussed by public, private, and civil society actors. Since multiple issues and actors compete for attention in issue arenas, only a few issues can remain relevant for a given length of time. What may be relevant in one network and its issue arenas may not be so in others. As discussed earlier, issue arena discussions follow the zero-sum principle, whereby only a certain number of issues can stay relevant at once, so that when one issue is picked up for discussion as salient, attention is diverted away from another previously salient issue [88]. In the documents, while many issues concerning human trafficking were mentioned, other issues may have lost the battle for public attention, and hence were not included. As many actors seek to participate in a process that may end in policy and law formulation that will support a resolution for their own salient issues, there is a massive oversupply of social problems in all issue arenas. Therefore, only a small fraction of these issues can gain the level of attention that is needed to enable solutions to be found. The tool used to make issues more salient is framing [21,22,25]. Thus, it is very important that well-established actors such as the EP, Amnesty and HRW deem human trafficking as salient, discuss it, and attempt to find real-world solutions to this problem.

The documents show that creating salience is often done by referring to values by, for example, stressing that children are involved in human trafficking or providing narratives about the various types of horrendous sexual, emotional and labor abuse that victims may repeatedly endure, thereby illustrating the cycle of re-victimization. Bandwagoning of issues is another form of framing, which is used to draw 
attention to a social issue $[30,31]$. Consequently, one would expect that this is done only when the connection is positive, but in our research we have found that human trafficking was also linked to more difficult topics such as migration. Drawing attention to another social problem is a selective process; thus, making a connection to another issue may not always add support as there may be a clash in viewpoints. For example, associating illegal migration with human trafficking may not increase support to combat human trafficking. Similarly, associations made with income differences may create less sympathy than the case of exploitation for organs or surrogacy. The less obvious correlations with human trafficking, such as associating sporting events with human trafficking, were reported very tactfully by the EP.

\subsection{Networks}

In the documents, various organizations who are actively involved reporting on human rights violations were cited and in this way given support, while other actors may not have been cited at all. This observation exemplifies how actors position themselves in the network by amplifying other actors' voices and creating connections with various powerful actors inside the network. In the EP documents, for example, the UNHCR was frequently mentioned as were the two NGOs that we have studied. The NGOs in turn similarly mentioned various political actors in their search for political solutions to various violations. By acknowledging other actors, alliances may be sought and real-world solutions drafted.

Amnesty, HRW and the EP play various roles in the debate on human trafficking. Though they are clearly not the only actors working on this issue, these actors are positioned as gatekeeper NGOs by demonstrating their expertise, through fact finding, and drafting real-world solutions. The documents of the EP present them as problem solvers, whereas they urge states and officials not to allow, facilitate, and/or sometimes benefit from human trafficking. The gatekeepers will push some issues and not others, demonstrating that they have a considerable amount of information power [28,31,50,54,57].

The EP is a highly relevant hub and it is connected to various political networks concerning a variety of topics, whereas Amnesty and HRW are gatekeepers of the human rights networks. Not all actors view an issue as equally salient. Only issues seen as salient by several actors are discussed in issue arenas. In some cases, the initiative of gatekeepers is needed to gain international attention [28] to cross-border issues such as trafficking. This actor role was visible in many places in the present documents. However, the documents did not show how other actors bring issues into the center of issue arenas. According to the literature, they must cooperate with a gatekeeper or provide a new outlook and frame, or engage in cooperation with others to win the support of other actors for the issues in question [28,89]. Because human trafficking is a complex issue with deep roots in society, collaborative learning in the actor networks involved and in the evaluation of measures is needed to reach sustainable solutions.

\subsection{Issue Transfer}

In issue arenas, actors interact when they discuss issues, which then may cause them to influence one another, potentially changing the course of the debate. Issues may also be transferred from discussions on the internet to the traditional political arena [21]. In our research, we found that several issue clusters were mentioned by different actors, including, in particular, the situation in Sahel and Sinai and related issues in countries such as Egypt, Sudan, and Israel. Although in this study issue transfer is not our 
primary focus, the dates of some of the documents indicate that actors listen to other actors, and are thus open to agenda setting. The EP focused on the human trafficking issue cluster in 2012, while Amnesty also addressed similar issues in 2012, having previously done so in 2011, and HRW focused on this issue cluster in 2012.

Similarly, another issue cluster, combining security and various human rights and social issues in the Balkans, Serbia, and Kosovo along with the accession of Croatia to EU membership, was discussed in various documents by the EP in 2011, whereas it was also addressed extensively by HRW, and to a lesser extent Amnesty, in both 2011 and 2012. Similarly, at the beginning of 2011, the EP published a resolution regarding the devastating humanitarian and social situation in Haiti after the earthquake. While Amnesty devoted much attention to human trafficking in Haiti in 2011 in various documents, HRW and the EP focused more on other issues such as illegal fishing and human trafficking.

It should be noted that these time-frame examples are taken only from the documents that were included in this study. Issue clusters may have been discussed elsewhere by the actors, and the number of discussions in other issue arenas is possibly higher. Furthermore, as this study has shown, issues are intertwined and several connections are made naturally by the actors, even if, in the present case, the word "human trafficking" was not mentioned. Consequently, to look only at the publication dates of a document may offer rather superficial information. A more in-depth study would demonstrate the interconnectedness of actors' agenda setting in more detail.

\section{Conclusions}

This research focused on how the international gatekeeper actors Amnesty International, Human Rights Watch and the European Parliament discussed human trafficking. We have investigated how social issues are debated prior to policy and law formation and how they influence the decision-making process. We have also observed how during the debate various viewpoints and alternatives for possible solutions may be emphasized or omitted. Thus, when examining human rights issues, it is as important to study the debate that occurs prior to policy and law formation that addresses these issues, as it is to study the endgame. The findings of the study showed that there is a dynamic interrelatedness between actors and the social issues that they are supporting and have documented, and how a political issue developed greater salience during a specific period of time.

In addition, the results highlight the way in which issues are framed and create the social context for subsequent policy and law formation. The context is seen as a result of processes of negotiation of meaning that is generated by the actors. Moreover, our research results provide insights into how information power was expressed by these important actors in a particular network through an emphasis on specific issues, actors and views. Similarities in views helped to create a basis for consensus building and subsequently facilitate solutions.

The NGOs mentioned human trafficking in more documents than the EP. By discussing the topic in a particular social context, they showed how it is intertwined with other issues, such as poverty and the poor functioning of juridical systems. The EP framed human trafficking in connection with other issues, such as gender-based violence and employment. The conclusions that were drawn by the NGOs and the EP had many similarities. The actors acknowledged each others' views, and they acknowledged other well-known actors such as the UN, confirming that they function as important hubs in this 
decision-making network. The EP also mentions other actors in order to acknowledge efforts that have been made towards solving an issue and to reinforce such efforts. Framing was used to show causal relations between issues, actors and context. Responsibility framing is used to identify the actors involved in creating or maintaining problems, such as criminal networks and officials who allow violations to continue or even add to them.

The bandwagoning of issues is used to increase salience, such as connecting an issue with already recognized issues such as organized crime but, above all, causal relations are explicated even if these, while contributing to public understanding of a complex issue, may not always be favorable for issue salience. Some issues were only mentioned by one actor, e.g., child labor in the mines of Mali by HRW, or fishing by EP, while Haiti was mentioned frequently by Amnesty and just once by EP, showing that these issues were not getting coverage by all the actors in the period investigated, as issues are selective. Some transfer of issues is seen where issues have been discussed earlier by the NGOs before being addressed even more comprehensively by the EP.

There seems to be a consensus among the gatekeepers that human trafficking is both a national and an international problem. The actors share the notion that human trafficking must be seen within a larger context of issues, as it is intertwined with multiple other issues, mainly various social injustices and violations that result from and feed off poverty, and the poor functioning of juridical and state systems. In various documents, the EP described situations related to human trafficking as very worrying, demanding a more result-oriented approach from the various parties involved, a notion that the two NGOs supported in their documents. The EP also noted that the global financial crisis has had a negative impact on gender-equality and said that decision makers should pay more than lip service to gender equality-related issues. The EP called for decision makers to make the prevention of gender-based violations a priority in their economic strategies. Amnesty, HRW and the EP used framing to underline causality between poverty, gender-based violence and gender inequality along with disruptive natural disasters, the collapse of states, and corruption in various forms of governance and policing. All the actors investigated called for international cooperation and treaties to be drawn up, and for the implementation of already-existing policies at the national legislative level.

This study focused on one particular human rights issue and 240 documents from three organizations retrieved across a two-year time span. Future research could focus more on elements such as issue transfer and include more actors. Additional research should be done to investigate the various cultural interpretations of what human trafficking is and how it is connected with other issues. This study contributes to a better understanding of how human trafficking is framed, the context in which it is discussed, and how it is intertwined with other issues. It has clarified how the actors used framing to increase issue salience and how they have emphasized the chain of causality between the root causes and effects on various other issues. Framing was used as method of placing responsibility on traffickers but also on decision makers and authorities. Moreover, the EP called for NGOs and civil society to participate in the process of preventing trafficking and helping victims, whilst the NGOs asked traditional political actors to take responsibility for state corruption. The targets of human rights violations, in this case mostly women and children, do not yet have a direct voice in the social and political debate, which is why the EP proposed including them in finding sustainable solutions.

Maintaining issue salience for human trafficking poses a challenge. Possibly, an issue of this magnitude and severity can only be kept at bay, and this already needs continuous action by many actors, 
and appropriate communication to understand it as a deeply rooted and multifaceted problem. Human trafficking is merely one of numerous serious social issues that demand urgent attention. Serious human rights violations occur daily across the world. Human rights are universal in theory but are nevertheless often violated. The UN Declaration of Human Rights promotes the protection of human rights of all people, and this should not be culturally bound and therefore selective. Not all people enjoy universal rights, and human rights violations warrant attention in public and political issue arenas. Moreover, not all actors deem the same human rights as salient. Different belief systems and cultural, political, and moral systems influence how social issues such as human trafficking are seen. The problem in issue arena discussions and subsequent decision-making processes concerning human trafficking may be that the issue has not yet gained enough salience or it seems to be simply too much of a challenge. It is also likely that the interrelatedness of social issues, and the context in which these issues take place, are not yet fully understood.

However, a shared understanding of the social context and the cause and blame with respect to human trafficking seem to be evident between the three actors. Human trafficking was seen in the early 1990s as a women's rights issue that was the concern of feminist groups and NGOs. Currently, human trafficking is regarded as a salient global political issue that needs attention. In the documents of Amnesty, HRW and the EP, the gatekeepers called for collaboration in finding political solutions. Paying attention to the multiple and complex concerns and how they are addressed in the debate about human trafficking may support this goal.

\section{Author Contributions}

The first author Niina Meriläinen designed the study together with the second author Marita Vos. Meriläinen gathered the data and wrote the manuscript together with Vos.

\section{Conflicts of Interest}

The authors declare no conflict of interest.

\section{References}

1. Pettigrew, A.M. The Politics of Organizational Decision-Making; Tavistock: London, UK, 1973.

2. Meriläinen, N.; Vos, M. Human rights organizations and online agenda setting. Corp. Commun. 2011, 16, 293-310.

3. Martens, K. Mission Impossible? Defining Nongovernmental Organizations. Voluntas. Int. J. Volunt. Nonprofit Organ. 2002, 13, 271-285.

4. Joachim, J. Framing Issues and Seizing Opportunities: The UN, NGOs, and Women's Rights. Int. Stud. Q. 2003, 47, 247-274.

5. Steinberg, G.M. The Politics of NGOs, Human Rights and the Arab-Israel Conflict. Israel Stud. 2011, 16, 24-54.

6. Murdie, A. The impact of human rights NGOs activity on human right practices. Int. NGO J. 2009, 4, 421-440.

7. Dahre, J. There are no such things as universal human rights—on the predicament of indigenous 
peoples, for example. Int. J. Hum. Rights 2010, 14, 641-657.

8. Ibhawoh, B. The Right to Development: The Politics and Polemics of Power and Resistance. Hum. Rights Q. 2010, 33, 76-104.

9. DeBono, D. "Less than human”: The detention of irregular immigrants in Malta. Race Class 2013, 55, 60-81.

10. Schott, R.M. War rape, natality and genocide. J. Genocide Res. 2011, 13, 5-21.

11. Alidadi, K.; Foblets, M. Framing multicultural challenges in freedom of religion terms: Limitations of minimal human rights for managing religious diversity in Europe. Neth. Q. Hum. Rights 2012, 30, 460-488.

12. Nash, K. The Cultural Politics of Human Rights: Comparing the US and UK; Cambridge University Press: Cambridge, UK, 2009.

13. Keck, M.; Sikkink, K. Activists beyond Borders: Advocacy. Networks in International Politics; Cornell University Press: Ithaca, NY, USA, 1998.

14. Okin, S.M. Feminism, Women's Human Rights, and Cultural Differences. Hypatia 1998, 13, 32-52.

15. Marsh, C.; Payne, D.P. The Globalization of Human Rights and the Socialization of Human Rights Norms. Brigh. Young Univ. Law Rev. 2007, 3, 665-688.

16. Miller, L.F. Rights of Self-delimiting Peoples: Protecting Those Who Want No Part of Us. Hum. Rights Rev. 2013, 14, 31-51.

17. Guttenplan, D.D.; Margaronis, M. Who Speaks for Human Rights? A Clash between a Feminist Activist and a Former Guantánamo Detainee Divides the Left. Available online: http://www.thenation.com/article/who-speaks-human-rights\#axzz2ef45u610 (accessed on 1 September 2013).

18. Donnelly, J. Human rights and human dignity: An analytic critique of non-Western conceptions of human rights. Am. Polit. Sci. Rev. 1982, 76, 303-316.

19. Hafner-Burton, E.M.; Tsutsui, K.; Meyer, J.M. International human rights law and the politics of legitimation repressive states and human rights treaties. Int. Sociol. 2008, 23, 115-141.

20. Luoma-Aho, V.; Vos, M. Towards a more dynamic stakeholder model: Acknowledging multiple issue arenas. Corp. Commun. 2010, 15, 315-331.

21. Meriläinen, N.; Vos, M. Framing issues in the public debate: The case of human rights. Corp. Commun. 2013, 18, 119-134.

22. Entman, R.M. Framing: Toward Clarification of a Fractured Paradigm. J. Commun. 1993, 43, 51-58.

23. McCombs, M.; Shaw, D. The Agenda-Setting Function of Mass Media. Public Opin. Q. 1972, 36, 176-187.

24. Sheafer, T.; Weimann, G. Agenda building, agenda setting, priming, individual voting intentions, and the aggregate results: An analysis of four Israeli elections. J. Commun. 2005, 55, 347-365.

25. Mahon, J.; Wartick, S.L. Dealing with Stakeholders: How Reputation, Credibility and Framing Influence the Game. Corp. Reput. Rev. 2003, 6, 19-35.

26. Lecheler, S.; de Vreese, C.H. Framing Serbia: The effects of news framing on public support for EU enlargement. Eur. Polit. Sci. Rev. 2010, 2, 73-93.

27. Zhu, J.-H. Issue Competition and Attention Distraction: A Zero-Sum Theory of Agenda-Setting. Journalism Mass Comm. Q. 1992, 69, 825-836. 
28. Bob, C. The International Struggle for New Human Rights; University of Pennsylvania Press: Philadelphia, PA, USA, 2009.

29. Hilgartner, S.; Bosk, C.L. The Rise and Fall of Social Problems: A Public Arenas Model. Am. J. Sociol. 1988, 94, 53-78.

30. Nicholson, S.; Chong, D. Jumping on the Human Rights Bandwagon: How Rightsbased Linkages Can Refocus Climate Politics. Glob. Environ. Polit. 2011, 11, 121-136.

31. Carpenter, R.C. Vetting the Advocacy Agenda: Network Centrality and the Paradox of Weapons Norms. Int. Organ. 2011, 65, 69-102.

32. Rodio, E.B.; Schmitz, H.P. Beyond norms and interests: Understanding the evolution of transnational human rights activism. Int. J. Hum. Rights 2010, 14, 442-459.

33. Kilburn, H.W. Personal Values and Public Opinion. Soc. Sci. Q. 2009, 90, 868-885.

34. Brewer, P.R.; Gross, K. Values, framing, and citizens' thoughts about policy issues: Effects on content and quantity. Polit. Psychol. 2005, 26, 929-948.

35. Busby, J.W. Bono Made Jesse Helms Cry: Jubilee 2000, Debt Relief, and Moral Action in International Politics. Int. Stud. Q. 2007, 51, 247-275.

36. Shen, F.; Edwards, H.H. Economic Individualism, Humanitarianism, and Welfare Reform: A Value-Based Account of Framing Effects. J. Commun. 2005, 55, 795-809.

37. Hughes, D.M. The "Natasha” Trade: The Transnational Shadow Market of Trafficking in Women. J. Int. Aff. 2000, 53, 625-651.

38. Agbu, O. Corruption and human trafficking: The Nigerian case. West. Afr. Rev. 2003, 4, 1-13.

39. Aston, J.N.; Paranjape, V.N. Abolishment of Human Trafficking: A Distant Dream. Available online: http://papers.ssrn.com/sol3/papers.cfm?abstract_id=2112455 (accessed on 12 September 2013).

40. Barner, J.R.; Okech, D.; Camp, M.A. Socio-Economic Inequality, Human Trafficking, and the Global Slave Trade. Societies 2014, 4, 148-160.

41. Sullivan, B. Trafficking in Human Beings. In Gender Matters in Global Politics: A Feminist Introduction to International Relations; Shepherd, L.J., Ed.; Routledge: London, UK, 2010; pp. 89-102.

42. Hankivsky, O. The Dark Side on Care: The Push Factors of Human Trafficking. In Feminist Ethics and Social Policy—Towards a New Global Political Economy of Care; Mahon, R., Robinson, F., Eds.; UBC Press: Vancouver, BC, Canada, 2011; pp. 145-161.

43. Nikolić-Ristanović, V. Human Trafficking Between Profit and Survival. In Crime and Transition in Central and Eastern Europe; Šelih, A., Završnik, A., Eds.; Springer: New York, NY, USA, 2012; pp. 205-227.

44. Shelley, L. The Relationship of Drug and Human Trafficking: A Global Perspective. Eur. J. Crim. Policy Res. 2012, 18, 241-253.

45. Van den Anker, C.; van Liempt, I. Human Rights and Migration: Trafficking for Forced Labour; Palgrave Macmillan: New York, NY, USA, 2012.

46. Chuang, J. Beyond a snapshot: Preventing human trafficking in the global economy. Indiana $J$. Glob. Legal Stud. 2006, 13, 137-163.

47. Maedl, A. Rape as Weapon of War in the Eastern DRC? The Victims' Perspective. Hum. Rights Q. 2011, 33, 128-147. 
48. Eurostat. Trafficking in human beings-2013 edition. Available online: http://epp.eurostat.ec.europa.eu/portal/page/portal/product_details/publication?p_product_code=K S-RA-13-005 (accessed on 23 September 2014).

49. Dembour, M.B.; Kelly, T. Introduction. In Are Human Rights for Migrants? Critical Reflections on the Status of Irregular Migrants in Europe and the United States; Dembour, M.B., Kelly, T., Eds.; Routledge: New York, NY, USA, 2011; pp. 1-16.

50. Lewin, K. Frontiers in group dynamics II. Channels of group life; social planning and action research. Hum. Relat. 1947, 1, 143-153.

51. Meriläinen, N.; Vos, M. Framing by Actors in the Human Rights Debate: The Kony 2012 Campaign. Nord. J. Hum. Rights 2014, 32, 238-257.

52. Pallas, C.L.; Urpelainen, J. Mission and Interests: The Strategic Formation and Function of North-South NGO Campaigns. In Proceedings of the International Studies Association Annual Convention, San Diego, CA, USA, 1-4 April 2012.

53. Dahl, R. The concept of power. Behav. Sci. 1957, 2, 201-215.

54. Bachrach, P.; Baratz, M.S. Two Faces of Power. Am. Polit. Sci. Rev. 1962, 56, 947-952.

55. Anton, A. Socialist Voices. In Toward a New Socialism; Schmitt, R., Anton, A., Eds.; Lexington Books: Plymouth, UK, 2007; pp. 21-52.

56. Lukes, S. Power: A Radical View; Macmillan: London, UK, 1974.

57. Barzilai-Nahon, K. Toward a theory of network gatekeeping: A framework for exploring information control. J. Am. Soc. Inf. Sci. Technol. 2008, 59, 1493-1512.

58. Bennett, W.L.; Foot, K.; Xenos, M. Narratives and network organization: A comparison of fair trade systems in two nations. J. Commun. 2011, 61, 219-245.

59. Petrocik, J.R. Issue Ownership in Presidential Elections, with a 1980 Case Study. Am. J. Polit. Sci. 1996, 40, 825-850.

60. Gregory, S. Transnational Storytelling: Human Rights, WITNESS, and Video Advocacy. Am. Anthropol. 2006, 108, 195-204.

61. DeLuca, K.M.; Lawson, S.; Sun, Y. Occupy Wall Street on the public screens of social media: The many framings of the birth of a protest movement. Comm. Cult. Crit. 2012, 5, 483-509.

62. Amnesty International. Available online: http://amnesty.org (accessed on 18 December 2014).

63. Human Rights Watch. Available online: http//hrw.org (accessed on 18 December 2014).

64. European Parliament/Legislative Observatory. Available online: http://www.europarl.europa.eu/ oeil/search/search.do (accessed on 18 December 2014).

65. Amnesty International Report 2012: Facts and Figures. Available online: http://www.amnesty.org/ en/library/info/POL10/003/2012/en (accessed on 18 December 2014).

66. Chad: Briefing to the UN Committee on the Elimination of Discrimination against Women, 50th Session, October 2011. Available online: http://www.amnesty.org/en/library/info/AFR20/009/2011 (accessed on 8 January 2015).

67. Europe: S.O.S. Europe: Human rights and migration control. Available online: http://www.amnesty.org/en/library/info/EUR01/013/2012/en (accessed on 18 December 2014).

68. Egypt: Broken promises: Egypt's military rulers erode human rights. Available online: http://www.amnesty.org/en/library/info/MDE12/053/2011/en (accessed on 18 December 2014).

69. Egypt: End Sinai Nightmare for Migrants. Available online: http://www.hrw.org/news/ 
2012/09/05/egypt-end-sinai-nightmare-migrants (accessed on 18 December 2014).

70. Codes of ethics and declarations relevant to the health professions. Fifth Edition: 2011 Update. Available online: http://www.amnesty.org/en/library/info/ACT75/002/2011/en (accessed on 18 December 2014).

71. Rights, support and protection of victims of crime: Minimum standards (2011/0129). Available online: http://www.europarl.europa.eu/oeil/popups/ficheprocedure.do?reference=2011/ 0129\%28COD\%29\&l=en (accessed on 18 December 2014).

72. Priorities and outline of a new EU policy framework to fight violence against women (2010/2209). Available online: http://www.europarl.europa.eu/oeil/popups/ficheprocedure.do?reference=2010/ 2209\%28INI\%29\&l=en (accessed on 18 December 2014).

73. Equality between women and men in the European Union-2011 (2011/2244). Available online: http://www.europarl.europa.eu/oeil/popups/ficheprocedure.do?reference=2011/2244\%28INI\%29 \&l=en (accessed on 18 December 2014).

74. Equality between women and men in the European Union-2010 (2010/2138). Available online: http://www.europarl.europa.eu/oeil/popups/ficheprocedure.do?reference=2010/2138\%28INI\%29 \&l=en (accessed on 18 December 2014).

75. Women's working conditions in the service sector (2012/2046). Available online: http://www.europarl.europa.eu/oeil/popups/ficheprocedure.do?reference=2012/2046\%28INI\%29 \&l=en (accessed on 18 December 2014).

76. Resolution on human rights and the security situation in the Sahel region (2012/2680). Available online: http:/www.europarl.europa.eu/oeil/popups/ficheprocedure.do?reference=2012/ 2680\%28RSP\%29\&l=en (accessed on 18 December 2014).

77. Resolution on the situation in Mali (2012/2603). Available online: http://www.europarl.europa.eu/ oeil/popups/ficheprocedure.do?reference=2012/2603\%28RSP\%29\&l=en $\quad$ (accessed on 18 December 2014).

78. Resolution on the use of sexual violence in conflicts in North Africa and the Middle East (2011/2661). Available online: http://www.europarl.europa.eu/oeil/popups/ ficheprocedure.do?reference=2011/2661\%28RSP\%29\&l=en (accessed on 18 December 2014).

79. Resolution on human trafficking in Sinai, in particular the case of Solomon W. (2012/2569). Available online: http:/www.europarl.europa.eu/oeil/popups/ficheprocedure.do?reference=2012/ 2569\%28RSP\%29\&l=en (accessed on 18 December 2014).

80. Negotiations on EU-Libya Framework Agreement (2010/2268). Available online: http://www.europarl.europa.eu/oeil/popups/ficheprocedure.do?reference=2010/2268\%28INI\%29 \&l=en (accessed on 18 December 2014).

81. Resolution on the human rights situation in the United Arab Emirates (2012/2842). Available online: http://www.europarl.europa.eu/oeil/popups/ficheprocedure.do?reference=2012/ 2842\%28RSP\%29\&l=en (accessed on 18 December 2014).

82. State of implementation of the EU Strategy for Central Asia (2011/2008). Available online: http://www.europarl.europa.eu/oeil/popups/ficheprocedure.do?reference=2011/2008\%28INI\%29 \&l=en (accessed on 18 December 2014).

83. EU Strategy for the Black Sea (2010/2087). Available online: http://www.europarl.europa.eu/ oeil/popups/ficheprocedure.do?reference=2010/2087\%28INI\%29\&l=en $\quad$ (accessed on 18 
December 2014).

84. Resolution on the European integration process of Kosovo (2011/2885). Available online: http://www.europarl.europa.eu/oeil/popups/ficheprocedure.do?reference=2011/2885\%28RSP\%29 \&l=en (accessed on 18 December 2014).

85. Resolution on the situation in Haiti one year after the earthquake: Humanitarian aid and reconstruction (2010/3018). Available online: http://www.europarl.europa.eu/oeil/popups/ ficheprocedure.do?reference=2010/3018\%28RSP\%29\&l=en (accessed on 18 December 2014).

86. Combating illegal fishing at the global level-The role of the EU (2010/2210). Available online: http://www.europarl.europa.eu/oeil/popups/ficheprocedure.do?reference=2010/2210\%28INI\%29 \&l=en (accessed on 18 December 2014).

87. European dimension in sport (2011/2087). Available online: http://www.europarl.europa.eu/oeil/ popups/ficheprocedure.do?reference=2011/2087\%28INI\%29\&l=en (accessed on 18 December 2014).

88. Downs, A. Up and down with ecology: The issue attention cycle. Public Interest 1972, 28, 38-50.

89. Keohane, R.O.; Nye, J.S., Jr. Power and interdependence in the information age. Foreign Aff. 1998, 77, 81-94.

(C) 2015 by the authors; licensee MDPI, Basel, Switzerland. This article is an open access article distributed under the terms and conditions of the Creative Commons Attribution license (http://creativecommons.org/licenses/by/4.0/). 